\title{
KAJ IAN POLITIK HUKUM TENTANG PERUBAHAN KEWENANGAN PEMBERIAN IZIN USAHA PERTAMBANGAN MINERAL DAN BATUBARA
}

\author{
Rizkyana Zaffrindra Putri', Lita Tyesta A.L.W. ${ }^{2}$ \\ Program Studi Magister IImu Hukum \\ Fakultas Hukum Universitas Diponegoro \\ litatyestalita@yahoo.com
}

\begin{abstract}
ABSTRAK
Undang-Undang Nomor 23 Tahun 2014 mengatur pemberian Izin Usaha Pertambangan (IUP)menjadi kewenangan pemerintah provinsi dan pemerintahpusat. Permasalahan tesis ini adalah apa politik hukum latar belakang perubahan kewenangan pemberianIUP dan apa dampak yuridis dari perubahan kewenangan pemberian IUP. Metode Penelitian yang digunakan dalam tesis ini adalah penelitian yuridis normatif. Spesifikasi penelitian yang digunakan adalah deskriptif analitis. Metode pengumpulan data dilakukan menggunakan data sekunder melalui studi pustaka. Hasil penelitian menyimpulkan bahwa latar belakang politik hukum perubahan kewenangan pemberian IUP adalah banyaknya penyimpangan dilakukan oleh pemerintah kabupaten/kota. Dampak yuridis perubahan tersebut adalah surat edaran menteri diterbitkan untuk menyelenggarakan urusan pemerintahan.
\end{abstract}

Kata Kunci: Perizinan Pertambangan; Perubahan Kewenangan; Politik Hukum 


\section{A. PENDAHULUAN}

\section{Latar Belakang}

Indonesia sejak dahulu terkenal dengan kekayaan sumber daya alamnya yang melimpah baik di bidang pertanian, perikanan dan bahkan pertambangan. Hal ini terlihat pula dalam sejarah bangsa Indonesia di masa lampau, dimana banyak para penjajah asing yang berusaha menguasai hasil-hasil sumber daya alam tersebut. Setelah kemerdekaan Indonesia, pengelolaan sumber daya alam dituangkan dalam Pasal 33 ayat (3) UndangUndang Dasar Negara Republik Indonesia Tahun 1945 (UUD NRI 1945) yang berbunyi "Bumi, air dan kekayaan alam yangterkandung di dalamnya dikuasai oleh negara dan dipergunakan sebesar-besarnya kemakmuran rakyat".Dikuasai oleh Negara memaknai Hak Penguasaan Negara atas aset kekayaan alam. Negara berdaulat mutlak atas kekayaan sumber daya alam, digunakan untuk sebesarbesarnya kemakmuran rakyat dimaknai Hak Kepemilikan yang sah atas kekayaan alam adalah rakyat Indonesia. ${ }^{3}$ Ini dapat dipahami bahwa pengelolaan sumber daya alam dilakukan oleh negara dan dipergunakan untuk kemakmuran rakyat.Pemerintah sebagai representasi negara, baik pusat maupun daerah memiliki keterlibatan dalam

${ }^{3}$ Adrian Sutedi, 2011,Hukum Pertambangan, Jakarta: Sinar Grafika, hlm. 24 pengelolaan hasil sumber daya alam, termasuk didalamnya hasil pertambangan yaitu dalam hal pengaturan (regulasi), pengusahaan (mengurus) dan pengawasan.Berkaitan dengan pengaturan pengelolaan sumber daya mineral, turunan Pasal 33 UUD 1945 adalah Undang-Undang Nomor 4 tahun 2009 tentang Pertambangan Mineral dan Batubara. Hal ini diperjelas dalam Pasal 4 ayat (1) yang berbunyi "Mineral dan batubara sebagai sumber daya alam tak terbarukan merupakan kekataan nasional yang dikuasai oleh negara untuk sebesarbesar kesejahteraan rakyat." Lebih lanjut dalam Pasal (2) dinyatakan bahwa "Penguasaan mineral dan batubara oleh negara sebagaimana dimaksud pada ayat (1) diselenggarakan oleh Pemerintah dan/atau pemerintah daerah." Berkaitan dengan proses izin usaha pertambangan mineral dan batubara tersebut, maka dalam sistem pemerintah telah diatur pembagian kewenangan antara Pemerintah Pusat, Pemerintah Provinsi, dan Pemerintah Kabupaten/Kota.Kewenangan tersebut berdasar pada Undang-Undang Nomor 32 Tahun 2004 tentang Pemerintahan Daerah yang diatur lebih spesifik dalam Peraturan Pemerintah Nomor 38 Tahun 2007 tentang 
Pembagian Urusan Pemerintah, Pemerintah Daerah Provinsi, Dan Pemerintah Daerah Kabupaten/Kota. ${ }^{4}$ Namun, saat ini telah dikeluarkan Undang-Undang Nomor 23 Tahun 2014 tentang Pemerintahan Daerah untuk mengganti Undang-Undang 32 Tahun 2004. Mengenai kaitannya dengan energi dan sumber daya mineral, bidang tersebut menjadi urusan pemerintahan konkuren pilihan yang dibagi antara Pemerintah Pusat dan Daerah Provinsi dan Daerah kabupaten/kota. Berbeda dengan undang-undang sebelumnya, pengurusan izin usaha pertambangan yang dimiliki oleh pemerintah kabupaten/kota beralih menjadi kewenangan pemerintah provinsi dan pemerintah pusat.

Dengan melihat kenyataan yang diuraikan, permasalahan yang dapat dirumuskan adalah sebagai berikut:

1. Apa politik hukum yang menjadi latar belakang perubahan kewenangan dalam pemberian izin usaha pertambangan?

2. Bagaimana dampak yuridis dari perubahan kewenangan pemberian izin usaha pertambangan dari Pemerintah Kota/Kabupaten ke Pemerintah Provinsi?

\footnotetext{
4 Lampiran Peraturan Pemerintah Nomor 38 Tahun 2007 tentang Pembagian Urusan Pemerintah, Pemerintah Daerah Provinsi, Dan Pemerintah Daerah Kabupaten/Kota bagian Pembagian Urusan Pemerintah Bidang Energi dan Sumber Daya Mineral
}

\section{Metode Penelitian}

Metode Penelitian yang digunakan dalam tesis ini adalah penelitian yuridis normatif. Spesifikasi penelitian yang digunakan adalah deskriptif analitis. Metode pengumpulan data dilakukan menggunakan data sekunder melalui studi pustaka. Metode analisis data menggunakan metode kualitatif.

\section{Kerangka Konsep}

\section{a. Politik Hukum}

Secara umum politik hukum terkait dengan hukum, yaitu hukum seperti apa yang akan digunakan untuk mengatur kehidupan bermasyarakat, berbangsa, dan bernegara. Politik hukum tersebut harus sesuai dengan nilai-nilai maupun pandangan hidup dari bangsa yang bersangkutan. Menurut Padmo Wahjono, politik hukum adalah kebijakan dasar yang menentukan arah, bentuk maupun isi hukum yang akan dibentuk. Selain itu, politik hukum juga merupakan kebijakan penyelenggara negara tentang apa yang dijadikan kriteria untuk menghukumkan sesuatu yang didalamnya mencakup pembentukan, penerapan dan penegakan hukum. ${ }^{5}$ Menurut Soedarto, Politik hukum adalah kebijakan negara melalui badanbadan negara yang berwenang untuk menetapkan peraturan-peraturan yang dikehendaki yang diperkirakan akan dipergunakan untuk mengekspresikan apa yang

\footnotetext{
5Moh. Mahfud MD, 2011,Politik Hukum di Indonesia, Jakarta: Raja Grafindo Persada, hlm. 1
} 
terkandung dalammasyarakat dan untuk mencpai apa yang dicita-citakan. ${ }^{6}$

\section{b. Pemerintahan Daerah}

Pemerintahan Daerah adalah penyelenggaraan urusan pemerintahan oleh pemerintah daerah dan dewan perwakilan rakyat daerah menurut asas otonomi dan tugas pembantuan dengan prinsip otonomi seluasluasnya dalam sistem dan prinsip Negara Kesatuan Republik Indonesia sebagaimana dimaksud dalam Undang-Undang Dasar Negara Republik Indonesia Tahun 1945.Sedang Pasal 18 ayat (5) UUD 1945 menyebutkan bahwa:

"Pemerintah daerah merupakan daerah otonom yang dapat menjalankan urusan pemerintahan dengan seluas-luasnya serta mendapat hak untuk mengatur kewenangan pemerintahan kecuali urusan pemerintahan yang oleh undang-undang ditentukan sebagai urusan pemerintahan pusat".

\section{c. Otonomi Daerah}

Secara etimologis, pengertian otonomi daerah berasal dari bahasa Latin yaitu "autos" yang berarti sendiri dan "nomos" yang berarti aturan. Jadi dapat diartikan bahwa otonomi daerah adalah mengurus dan mengatur rumah tangganya sendiri.7Dalam bahasa Inggris, otonomi berasal dari kata "autonomy", dimana "auto" berarti sendiri dan "nomy" sama artinya dengan "nomos" yang berarti aturan atau

6lbid

7 Ni'matul Huda, 2009,Hukum Pemerintahan Daerah, Konsep Otonomi Daerah, Bandung: Nusa Media, hlm.93
Undang-Undang. Jadi "autonomy" adalah mengatur diri sendiri. Sementara itu, pengertian lain tentang otonomi ialah sebagai hak mengatur dan memerintah diri sendiri atas inisiatif dan kemauan sendiri. Hak yang diperoleh berasal dari pemerintah pusat. ${ }^{8}$

Berdasarkan Undang-Undang Nomor 23 Tahun 2014 tentang Pemerintahan Daerah dirumuskan definisi dari otonomi daerah yakni hak, wewenang, dan kewajiban daerah otonom untuk mengatur dan mengurus sendiri Urusan Pemerintahan dan kepentingan masyarakat setempat dalam sistem Negara Kesatuan Republik Indonesia. ${ }^{9}$ Pada hakikatnya Otonomi Daerah diberikan kepada rakyat sebagai satu kesatuan masyarakat hukum yang diberi kewenangan untuk mengatur dan mengurus sendiri Urusan Pemerintahan yang diberikan oleh Pemerintah Pusat kepada Daerah dan dalam pelaksanaannya dilakukan oleh kepala daerah dan DPRD dengan dibantu oleh Perangkat Daerah. Urusan Pemerintahan yang diserahkan ke Daerah berasal dari kekuasaan pemerintahan yang ada ditangan Presiden. Konsekuensi dari negara kesatuan adalah tanggung jawab akhir pemerintahan ada ditangan Presiden. Agar pelaksanaan Urusan Pemerintahan yang diserahkan ke Daerah berjalan sesuai dengan kebijakan nasional maka Presiden berkewajiban untuk melakukan

8 Sujamto, 1993,0tonomi Daerah yang Nyata dan Bertanggungjawab, Jakarta: Ghalia Indonesia, hlm. 15 9Pasal 1 ayat (5) UU 23 Tahun 2014 
Jurnal Law Reform

Volume 11, Nomor 2, Tahun 2015

pembinaan dan pengawasan terhadap penyelenggaraan Pemerintahan Daerah. ${ }^{10}$

B. HASIL PENELITIAN DAN PEMBAHASAN 1. Politik Hukum Latar Belakang Perubahan Kewenangan Pemberian Izin Usaha Pertambangan

Politik Hukum merupakan kebijakan-kebijakan hukum pemerintah yang akan dikeluarkan dalam bentuk kebijakan-kebijakan dan peraturanperaturan seperti undang-undang, Perpu, PP, Perpres, Perda. Pembentukan kebijakan hukum dijalankan oleh lembagalembaga yang berwenang untuk mengeluarkan kebijakan hukum berdasarkan cita Negara, cita hukum dan tujuan negara yang terdapat dalam konstitusi atau hukum dasar suatu negara yang dijadikan dasar rujukan dalam pembentukan peraturan perundangundangan. Dalam pengertian inilah pijakan utama politik hukum nasional adalah tujuan negara yang kemudian melahirkan sistem hukum nasional yang harus dibangun dengan pilihan isi dan cara tertentu. Karakteristik kebijakan atau arah yang dituju oleh Politik Hukum Nasional dalam masalah pembangunan politik hukum nasional sebagai bentuk dari kristalisasi kehendak-kehendak rakyat.

Menurut hasil penelitian penulis, perubahan kewenangan pemberian Izin Usaha Pertambangan (IUP) didasari oleh beberapa alasan, yaitu:

1. Banyak terjadi penyimpanganpenyimpangan hukum di bidang perizinan pada tataran pemerintahan Kabupaten/Kota.

2. Rendahnya jaminan kepastian hukum dan kepastian investasi untuk investor

\section{Dampak Yuridis Perubahan} Kewenangan Pemberian Izin Usaha Pertambangan

Setelah diundangkannya UndangUndang Pemerintahan Daerah yang baru, kewenangan pemerintah kabupaten/kota terhadap pengelolaan izin usaha pertambangan dihapuskan dan dialihkan kepada pemerintah pusat dan pemerintah provinsi. Namun perubahan ini tidak serta merta merubah sistem dan mekanisme perizinan yang telah berlaku sebelumnya.

Sistem dan mekanisme mengenai permohonan izin usaha pertambangan tetap dilaksanakan sesuai ketentuan perundang-undangan yang berlaku, yaitu Undanng-Undang Nomor 4 Tahun 2009 tentang Pertambangan Mineral dan Batubara serta peraturan pelaksananya yaitu Peraturan Pemerintah Nomor 23 Tahun 2010 tentang Pelaksanaan Kegiatan Usaha Pertambangan Mineral dan Batubara. Perubahan hanya terletak pada 
kewenangan pemberian izin yang pada awalnya adalah wewenang Walikota/Bupati menjadi kewenangan Gubernur. Sistem dan mekanisme yang telah berjalan sedemikian rupa tidak mudah untuk dirubah, maka dalam pelaksanaannya permohonan izin ussaha pertambangan tetap menggunakan ketentuan yang telah berlaku.

Sehubungan dengan berlakunya undang-undang pemerintahan daerah yang mengalihkan kewenangan perizinan izin usaha pertambangan, dampak yuridis yang dirasakan adalah ketentuan-ketentuan yang berhubungan dengan hal tersebut tentunya akan berubah, namun dalam pelaksanaannya ketentuan lama masih dipergunakan dan belum adanya ketentuan-ketentuan baru yang menyesuaikan dengan aturan tersebut. $\mathrm{Hal}$ ini dikarenakan Undang-Undang Nomor 23 Tahun 2014 belum memiliki peraturan pelaksana, yang mana menjadi petujuk teknis untuk menyusun peraturan baru mengenai perubahan kewenangan izin usaha pertambangan. Namun, belum adanya peraturan pelaksana yang mengatur mengenai perubahan izin kewenangan tersebut, terdapat beberapa peraturan yang dikeluarkan Kementerian terkait dengan perubahan kewenangan izin usaha pertambangan:
1. Surat Edaran Menteri Dalam Negeri Nomor 120/253/SJ tentang Penyelenggaraan Urusan Pemerintah Setelah Ditetapkan Undang-Undang Nomor 23 Tahun 2014

Berhubungan dengan perubahan kewenangan perizinan usaha pertambangan, surat edaran menteri dalam negeri khususnya dalam poin terakhir mengenai kordinasi antara gubernur dengan bupati/walikota dalam rangka pengalihan urusan pemerintahan konkuren ini merupakan acuan yang menjadi dasar untuk pelaksanaan kewenangan gubernur untuk menerbitkan izin usaha pertambangan. Hal ini mengisyaratkan bahwa gubernur dengan bupati dan walikota bekerja sama dalam melaksanakan ketentuan pengalihan urusan pemerintahan konkuren yang diamanatkan oleh Undang-Undang Nomor 23 Tahun 2014. Bupati/walikota yang sebelumnya berhak untuk mengeluarkan izin usaha pertambangan di wilayah kabupaten/kota tidak serta merta kehilangan tugas yang berkaitan dengan izin usaha pertambangan. Gubernur sebagai wakil pemerintah pusat untuk menerbitkan izin usaha pertambangan dapat meminta bantuan kepada bupati/walikota dan dinas terkait untuk mempersiapkan dokumen- 
Jurnal Law Reform

Volume 11, Nomor 2, Tahun 2015

dokumen terkait dengan perizinan di wilayah kabupaten/kota dengan melalui Tugas Pembantuan.

2. Surat Edaran Menteri Energi dan Sumber Daya Mineral Nomor 02.E/30/DJB/2015 tentang Izin Usaha Pertambangan Badan Usaha Milik Negara

Surat Edaran ini berisikan tentang kewajiban gubernur atau bupati/walikota menyerahkan dokumen IUP BUMN yang mana merupakan kewenangan pemerintah pusat untuk menerbitkan Izin Usaha Pertambangan dalam rangka Penanaman Modal Asing.

\section{PENUTUP}

\section{SIMPULAN}

Berdasarkan uraian yang telah penulis paparkan, maka dapat disimpulkan sebagai berikut:

1. Politik hukum yang menjadi latar belakang terjadinya perubahan kewenangan pemberian izin usaha pertambangan dari pemerintah kabupaten/kota ke pemerintah provinsi dan pemerintah pusat, diantaranya:

- Segi internal, perubahan kewenangan ini didasari banyaknya penyimpangan yang dilakukan oleh pemerintah kabupaten/kota baik dari unsur politik maupun hukum.
Program Studi Magister Ilmu Hukum Fakultas Hukum Universitas Diponegoro

- Segi eksternal, perubahan kewenangan ini juga dipengaruhi oleh kepentingan investor yang akan menanamkan modalnya pada sektor pertambangan. Investor menghendaki agar terciptanya kepastian hukum dan kepastian investasi dalam pelaksanaan usaha pertambangan.

2. Dampak yuridis dari perubahan kewenangan pemberian izin usaha pertambangan adalah pada waktu penulisan tesis ini, belum terdapat peraturan pelaksana undang-undang, maka dari itu diterbitkannya surat edaran menteri dalam negeri yang berisi mengenai penyelenggaraan urusan pemerintah setelah ditetapkan UndangUndang Nomor 23 Tahun 2014. Surat edaran ini menegaskan bahwa pemerintah kabupaten/kota tetap berkewajiban membantu pemerintah provinsi dan pemerintah pusat untuk berkoordinasi mengenai pemberian izin usaha pertambangan meskipun kewenangannya telah beralih. Kewenangan pemerintah kabupaten/kota didasarkan pada Tugas Pembantuan yang diberikan oleh pemerintah provinsi atau pemerintah pusat. Meskipun demikian, surat edaran tersebut tidak bisa dijadikan dasar yang kuat untuk pelaksanaan aturan tersebut, pemerintah tetap harus mengeluarkan peraturan pelaksana untuk mengatur 
Jurnal Law Reform

Volume 11, Nomor 2, Tahun 2015

pembagian urusan pemerintahan secara jelas.

\section{SARAN}

Adapun saran yang ingin disampaikan Penulis berdasarkan beberapa simpulan diatas adalah sebagai berikut:

1. Pelimpahan urusan pemerintahan dari pemerintah pusat kepada pemerintah daerah baik pemerintah provinsi dan pemerintah kabupaten/kota khususnya dalam hal pengelolaan sumber daya mineral dan batubara seharusnya dikaji kembali berdasarkan asas desentralisasi dan otonomi daerah sehingga tidak terjadi penyimpangan-penyimpangan yang dapat berakibat buruk bagi pemerintah maupun investor.

2. Peraturan di bidang pertambangan khususnya dalam hal Izin Usaha Pertambangan seharusnya dibenahi agar tidak terjadi disharmonisasi (tumpang-tindih) antar peraturan sehingga dapat mengembangkan investasi di bidang pertambangan dan mengolah sumber daya alam Indonesia untuk sebesar-besarnya kemakmuran rakyat.

3. Seiring dengan pergantian perundangundangan yang mengatur tentang Pemerintahan Daerah, maka sudah seharusnya peraturan-peraturan lainnya yang berhubungan mengikuti ketentuanketentuan yang baru yang diatur dalam
Program Studi Magister IImu Hukum Fakultas Hukum Universitas Diponegoro

Undang-Undang Nomor 23 Tahun 2014 tentang Pemerintahan Daerah.

\section{DAFTAR PUSTAKA}

\section{Literatur:}

Asshiddiqie, Jimly, 2010,Konstitusi dan Konstitusionalisme Indonesia, Jakarta:Sinar Grafika

Huda, Ni'matul, 2009,Hukum Pemerintahan Daerah, Konsep Otonomi Daerah, Bandung: Nusa Media

MD, Moh. Mahfud, 2010, Membangun Politik Hukum Menegakkan Konstitusi, Jakarta: Raja Grafindo Persada,

2011,Politik Hukum di Indonesia, Jakarta: Raja Grafindo Persada

Sujamto, 1990, Otonomi Daerah yang Nyata dan Bertanggungjawab,Jakarta: Ghalia Indonesia

Sutedi, Adrian, 2011,Hukum Pertambangan, Jakarta: Sinar Grafika

Undang-Undang:

Undang-Undang Nomor 32 Tahun 2004 tentang Pemerintahan Daerah

Undang-Undang Nomor 4 Tahun 2009 tentang Pertambangan Mineral dan Batubara

Undang-Undang Nomor 23 Tahun 2014 tentang Pemerintahan Daerah 